\title{
The detection and quantification of a digenean infection in the snail host with special emphasis on Fasciola sp.
}

\author{
Yannick Caron • Daniel Rondelaud • Bertrand Losson
}

Received: 29 May 2008 / Accepted: 5 June 2008 / Published online: 24 June 2008

(C) Springer-Verlag 2008

\begin{abstract}
In this review, ten methods used to study digenean infections in their intermediate hosts were compared to determine which one should be used either in the field or in the lab to establish the prevalence and intensity of infections in snails. Snail crushing and snail dissection allow quick establishing of prevalence in natural or experimental infections, whereas histology is considered as the most accurate approach to assess the intensity of infection. The follow-up of cercarial shedding only gave an idea on cercarial production. Among recently developed techniques, polymerase chain reaction (PCR) brings the most accurate information and shows high sensitivity and specificity levels when compared to blotting techniques. The easiness and relatively low cost of the basic PCR protocol make it interesting to investigate the epidemiology of the liver fluke in a lab with limited financial resources. Nevertheless, if this technique allows a relatively good estimation of the prevalence, information concerning the intensity of infection is best obtained through real time PCR. However, at the time being this technique is too expensive to be used routinely in the field. The choice between classical or new techniques is usually based on a compromise, as each technique has its advantages and drawbacks.
\end{abstract}

\footnotetext{
Y. Caron $(\triangle) \cdot B$. Losson

Faculty of Veterinary Medicine,

Department of Infectious Diseases, University of Liège,

20 Boulevard de Colonster, B-43a,

4000 Liège, Belgium

e-mail: ycaron@ulg.ac.be

D. Rondelaud

UPRES EA no. 3174, Faculty of Medicine,

2 rue du Docteur Raymond Marcland,

87025 Limoges Cedex, France
}

\section{Introduction}

In the life cycle of a digenean, several species of snails can act as intermediate hosts. However, the aptitude of the different species of snails to maintain the parasite life cycle during natural or experimental infections varies according to snail species and more particularly to the age of the snails when exposed to miracidia. For example, in the case of Fasciola hepatica, Galba truncatula is the main intermediate host in the Old World (Taylor 1965; Torgerson and Claxton 1999) but most of the other lymnaeid species of western Europe may also sustain the larval development of the liver fluke if they are exposed to miracidia during their first days of life (Boray 1978). To determine the ability of a snail species or a snail population to act as an intermediate host of a given species of digenean, it is necessary to measure several parameters such as the prevalence and intensity of snail infection, and metacercarial production (Graczyk and Fried 1999).

Several methods were developed by different authors to detect natural or experimental digenean infections in potential snail intermediate hosts and assess their parasite burdens. Snail crushing and/or dissection, with examination of the soft tissues under a dissecting microscope, are still widely used to detect a natural infection in snails collected from the field (Taylor 1965). Cercarial shedding during the patent period (Taylor 1965) is also commonly used. Examination of serial tissue sections from infected snails can also be used to determine the development of the redial burden and analyze the response of infected tissues (Barber 1962; Rondelaud and Barthe 1980a, 1983). However, the sensitivity and/or specificity of these classical techniques can be problematic and consequently, the development of highly sensitive and specific methods for detecting the liver fluke (and other digeneans) in the snails was undertaken (Kaplan et al. 1995). In 1982 already, enzymatic electrophoresis was developed (Van 
Aken 1982). In 1985, a strategy for amplifying target DNA sequences via in vitro DNA replication (polymerase chain reaction, (PCR)) was first described (Saiki et al. 1985). DNA or RNA probe based assays allow the study of Fasciola sp. genome and the elaboration of different PCR protocols, like multiplex or real time PCRs. Ideally these techniques should be used in the field.

As the results obtained for a given parameter in a given snail population showed variations according to the technique used, one may wonder what method is to be used for investigating the level of infection in the snails. The aim of the present review is to compare the different techniques available for the specific detection of Fasciola sp. in G. truncatula and other potential lymnaeids intermediate hosts. This should allow selection of the most appropriate technique in a given situation and for a specific purpose.

\section{Techniques based on microscopy}

As already mentioned the first available techniques (crushing, dissection, cercarial shedding, and/or histology) were extensively used before the introduction of molecular biology.

\section{Snail crushing and dissection}

The earliest and simplest method to detect a digenean infection was snail crushing. As the shell of $G$. truncatula is small $(\leq 12 \mathrm{~mm})$ and often very thin, especially in populations living on acid soils, the snail is squashed in a waterfilled Petri dish by applying the jaws of a fine forceps on the last whorl of the shell. If live larval forms of $F$. hepatica are present, they can be easily observed among the fragments of the shell and snail's viscera. This is an easy and fast way to evaluate the prevalence of infection in snails collected from the field (Dreyfuss et al. 2005). However, the intensity of infection is difficult to establish, as only live free rediae and free cercariae present within the snail's hemocoel can be counted. Indeed, the sporocysts of $F$. hepatica, the immature or degenerated rediae (Rondelaud and Barthe 1980b) and a few free cercariae, often located within the snail's foot and mantle, cannot be observed. In the same way, the encystment of released cercariae into metacercariae on the dish walls is scarce making this technique unsuitable to study cercarial emission and metacercarial encystment.

To overcome these difficulties, snail dissection is preferable. After destruction of the shell, the dissection of viscera and their examination under a dissecting microscope or a microscope allow to record the numbers of live or degenerated free rediae and cercariae, whatever their state of maturity. This technique was used by numerous authors (Abrous et al. 1999, 2000; Mage et al. 2002) to follow the intensity of natural infections with $F$. hepatica in $G$. truncatula populations living in swampy meadows on acid soils. Snail dissection was, for example, used to count sporocysts of Fascioloides magna in the foot and mantle of G. truncatula in the days following miracidial penetration (Erhardová-Kotrlá 1971). A similar method was also used by several authors to follow the development of redial generations in $G$. truncatula infected by F. hepatica (Belfaiza et al. 2004a, b, 2005), or to detect the presence of $F$. hepatica rediae in Pseudosuccinea columella 2 weeks after snail exposure to miracidia (Pointier et al. 2007). When compared to the first method, the calculation of the infection rate in snails infected with $F$. hepatica gives similar results. However, the parasite load is better evaluated, as it takes into account more rediae and all free cercariae present in the snail. Counting $F$. hepatica sporocysts is always difficult or even impossible, as these larvae are located in the mantle, a tentacle, or the kidney so that they cannot be observed. If the foot of the snail is removed from the Petri dish, many cercariae may encyst into metacercariae on the dish walls (Vignoles et al. 2008) and this allows to determine their state of maturity.

\section{Monitoring of cercarial shedding}

This approach was already used by the authors who had worked on the life-cycle of $F$. hepatica as early as 1880 (Taylor 1965). In the Bulinus truncatus/Schistosoma haematobium model, for example, sunlight stimulated cercarial shedding (Moukrim et al. 1995). However, this method is unsuitable for snails infected by digeneans other than Schistosoma sp. In the case of $F$. hepatica, cercarial shedding is recorded in the course of week 6 or 7 after maintenance at a temperature of $20^{\circ} \mathrm{C}$. This interval is progressively reduced when the snails are maintained at increasing temperatures (Kendall and McCullough 1951; Hodasi 1972; Audousset et al. 1989). There are two main drawbacks at this technique. The first is the intermittent production of cercariae over time so that no shedding of $F$. hepatica may occur for a week or more (Kendall and McCullough 1951; Audousset et al. 1989). Secondly, variable numbers of infected snails died without shedding cercariae, as demonstrated in 70 different populations of $G$. truncatula infected with $F$. hepatica (Vignoles et al. 2002) (Table 1). As the prevalence of infection in snails can only be estimated through cercarial shedding, it is grossly underestimated. In the same way, the intensity of infection is difficult to establish as cercarial shedding is the only criterion taken into account. This last drawback can be overcome through the dissection of snail cadavers and the assessment of their larval burden (Dreyfuss and Rondelaud 1995). Additionally, the monitoring of cercarial shedding is time-consuming and the maintenance of infected snails required a specific material when compared with the use of squashing or dissection methods. According to our own experience, this method must be restricted to the study of cercarial shedding. 
Table 1 Relationship between the prevalence of infection with $F$. hepatica in experimentally exposed snail populations ( $n=70)$ and the completion of the life cycle

\begin{tabular}{lccc}
\hline $\begin{array}{l}\text { Prevalence of Fasciola } \\
\text { hepatica infections }\end{array}$ & Number of snail populations & \multicolumn{2}{c}{ Mean frequency for each group of infected snails (in \%) } \\
\cline { 3 - 4 } & & Cercarial shedding & $\begin{array}{c}\text { No shedding but free cercariae and/or } \\
\text { rediae containing cercariae present }\end{array}$ \\
\hline$>60 \%$ & 17 & 56.8 & 29.3 \\
$40-59 \%$ & 15 & 53.5 & 31.3 \\
$20-39 \%$ & 23 & 50.1 & 32.3 \\
$5-19 \%$ & 11 & 14.0 & 58.0 \\
$<5 \%$ & 4 & 0 & 0 \\
\hline
\end{tabular}

Snails were classed into three categories: cercarial shedding, infection but no cercarial shedding, and snails containing sporocysts and/or immature rediae only (Vignoles et al. 2002)

${ }^{a}$ Snails containing sporocysts and/or immature rediae only

\section{Histological examination}

If larval forms of a digenean are present in a snail during its dissection, they need to be first identified before fixation. Indeed, histological examination does not allow parasite speciation, as sporocysts of all digeneans have the same aspect. As a consequence, this technique cannot be used to study parasite development during natural infections of snails. However, histological examination of experimentally infected snails allows an accurate count of the different larval forms (sporocysts, rediae, or cercariae), the evaluation of their physiological status (alive or degenerating) and of their location within the snail. In the case of $F$. hepatica, this method was used to study the development of redial generations (Rondelaud and Barthe 1982, 1987) and, also, the response of snail's viscera to larval development (Barber 1962; Rondelaud and Barthe 1980a, 1983). This technique is really interesting to determine the level of infection in the snails but a fairly long period of time (from 15 to 30 days) is required between exposure to miracidia and histological examination. Consequently, it is not appropriate for a rapid evaluation of the prevalence of infection in a given snail population. Finally it is a fairly expensive technique which is unsuitable for the routine monitoring of infection in large snail populations.

\section{Iso-enzymatic and molecular biology techniques}

In this part, we will describe the technical features, the sensitivity, and the specificity of each method. These techniques can be classified in two groups: biochemical (enzymatic electrophoresis) and molecular biology (blotting and PCR) techniques.

\section{Biochemical technique}

In 1982, Van Aken used a practical application of the thin-layer starch gel electrophoresis to reveal enzyme patterns of the glucose phosphate isomerase (GPI; E.C. 5.3.1.9.) of the larval stages of F. hepatica in G. truncatula (Van Aken 1982; Van Aken and Brandt 1987). Thin-layer starch gel electrophoresis was able to detect a broad spectrum of diagnostic isoenzymes (Dassler and Schmiedel 1989) and was used in helminthology for the identification of taeniid cestodes (Le Riche and Sewell 1977, 1978b) and different strains of Echinococcus granulosus (Le Riche and Sewell 1978a). At the present time, enzyme electrophoresis is principally used to characterize isolates of parasites, for example Leishmania sp. (Calvopina et al. 2006) or Trypanosoma sp. (Yeo et al. 2007). The starch gel is prepared and poured in a glass mould. In the meantime, the infected snails are individually homogenized with an enzyme stabilizing solution. A cotton strand is soaked in this mixture and placed into a slot on the gel. This gel is placed on a plate connected to two compartments containing phosphate buffer with Whatman paper. Electrophoresis is performed during $3 \mathrm{~h}$ and an agar overlay containing the developing solution plus meldolablue is gently poured on the starch gel and an incubation $\left(37^{\circ} \mathrm{C}\right)$ will follow until banding appears (Van Aken 1982). Snails individually exposed to one, two, or five to seven miracidia were electrophoretically analyzed at five, 12 , 19, 26, and 33 days after exposure. No difference was observed between the GPI-patterns of adult or larval $F$. hepatica homogenates, both being situated more cathodally than the bands obtained from uninfected G. truncatula.

In the case of snails infected with one or two miracidia, the presence of larvae could be demonstrated, but not earlier than 12 days post-infection. When five or seven miracidia were used for infection, it was possible to demonstrate the infection from day 5 (Van Aken 1982). With this technique, it seems difficult to detect $F$. hepatica in the snail before day 5 postinfection. Outside the $F$. hepatica/G. truncatula model, no experiments concerning specificity were conducted.

\section{RNA-based blotting}

The use of nucleic acid techniques in the diagnosis of parasitic infection has become increasingly widespread (Hubscher 
1991; Barker 1994; Weiss 1995; Prichard 1997; Gasser 1999). RNA or DNA can be separated on the basis of size and charge by electrophoresis and then transferred to a nylon membrane and exposed to a specific marqued probe. This probe will bind to similar sequences. The process in which single-stranded DNA is hybridized to a single strand of DNA following electrophoresis is called Southern blot. The DNA can originate from RNA by reverse transcriptase reaction (RT) and is called complementary DNA (cDNA). These techniques were developed in the beginning of the 1990s. Nucleic acid probes derived from ribosomal RNA (rRNA) were developed successfully for several organisms including Aeromonas salmonicida, Plasmodium berghei, and Tritrichomonas feetus (Barry et al. 1990; Waters and McCuthan 1990; Severson 1991). In 1992, Shubkin et al. developed this kind of technique for F. hepatica. Experimental infection with $F$. hepatica in P. columella was detected by reverse transcription PCR (RT-PCR) that amplified fragments of $F$. hepatica rRNA. Total RNA obtained from adult liver flukes was used in a polymerase chain reaction to isolate and amplify a region of approximately $650 \mathrm{bp}$ in the small subunit rRNA. This portion of the ribosomal cDNA, which contains highly conserved regions as well as variable regions, was subcloned and sequenced. A sequence unique to $F$. hepatica was identified and an oligonucleotide probe (CS4) of $20 \mathrm{bp}$ for detection of the liver fluke was first developed. A Southern blot analysis using CS4 and ${ }^{32} \mathrm{P}$ successfully identified small subunit rRNA from $F$. hepatica (Shubkin et al. 1992). The first technique was then improved and tested in an epidemiological study (Rognlie et al. 1994, 1996). In this case the RT reaction uses a non-specific primer (CS9) to produce cDNA from a rRNA template. Then fasciolid cDNA is amplified by the PCR using a second primer sequence (CS11) specific to fasciolids (Rognlie et al. 1994). This amplified sequence contained the fasciolid-specific probe hybridization site (CS6) that is a little bit longer than the CS4 sequence. The seasonal transmission of $F$. hepatica was then studied under natural conditions in Montana (USA) in batches of Lymnaea modicella and Lymnaea bulimoides (Rognlie et al. 1996).

Blotting analysis revealed that RNA isolated from a single miracidium was not detectable, whereas RNA derived from five miracidia was detected (Shubkin et al. 1992). In later experiments, the detection limit for purified fluke RNA was $10 \mathrm{fg}$ and an approximative 100-fold increase in sensitivity was achieved through Southern blot. Using this technique, infection in snails was detectable as early as one to 37 days post exposure (Rognlie et al. 1994). The reliability of this assay was assessed. There was not false positive but $11 \%$ of false negative results were recorded (Rognlie et al. 1994). The latter might be due, either to a true technical problem, or to the absence of parasitic development in exposed snails (Rognlie et al. 1994). To examine sensitivity further, various numbers of snails exposed to three to five miracidia were combined with unexposed snails and total RNA was extracted. The assay was able to detect a single infected snail out of 20 (Rognlie et al. 1994). In an epidemiological study (Rognlie et al. 1996), batches, each containing a maximum of 25 snails, were screened for fasciolid-specific ribosomal RNA sequence. Three thousand and seventy two individual lymnaeid snails were tested for infection and one batch contained liver fluke rRNA (Rognlie et al. 1996).

This technique allows the detection of $F$. hepatica in $P$. columella and L. modicella, with an oligonucleotide probe derived from a rRNA sequence. The oligonucleotide probe did not hybridize with the RNA of these two snail species, nor non-lymnaeid (Aplexa elongata, Gyraulus sp., and Oxyloma sp.) species (Shubkin et al. 1992; Rognlie et al. 1994, 1996). F. magna RNA and probably Fasciolopsis buski RNA were detected through Southern blot; cross reactivity with Fasciola gigantica was not checked. The assay is not expected to cross-react with other trematodes outside the family Fasciolidae (Rognlie et al. 1994). The oligonucleotide sequences (CS6 and CS11) were aligned with several rRNA sequences from organisms that could be considered as field contaminants (Saccharomyces cerevisiae, Fucus distichus, Aspergillus fumigatus, and Escherichia coli) with significant differences ruling out cross-reaction (Rognlie et al. 1994).

\section{DNA-based blotting}

DNA probes for the identification and detection of parasites, either in their definitive hosts or in different intermediate hosts, have been shown to be useful diagnostic and epidemiologic tools (Kukla et al. 1987; Delves et al. 1989; Webster et al. 1989). The first DNA-based technique that aimed to detect specifically $F$. hepatica in snails was described in 1993 (Heussler et al. 1993). F. hepatica DNA was extracted and digested with Bam HI. A distinct banding pattern of repetitive DNA sequences could clearly be detected. DNA fragments corresponding to these regions were isolated and cloned in a plasmid vector. Four clones, corresponding to highly repetitive DNA fragments, were isolated and tested by Southern blot hybridization to the DNA of various trematodes for specificity and sensitivity. The four probes detected parasite material in snail squash blots and no hybridization with snail DNA was observed. These four probes did not cross-react with $G$. truncatula DNA. Three probes, named Fhr-I, Fhr-II and Fhr-III, hybridized only to $F$. hepatica DNA whereas the Fhr-IV cross-hybridized with the DNA of various other trematode species (Dicrocoelium dendriticum, Xiphidiocercaria sp., Diplostoma sp., Trichobilharzia sp., and Dendritobilharzia sp.) and showed over 90\% homology with the 18S rRNA genes of trematodes such as Opisthorchis viverrini and various Schistosoma sp. (Heussler et al. 1993). The probes were not tested for F. magna nor Paramphistomum sp. 
In 1995, Kaplan and colleagues developed a repetitive DNA probe for the sensitive detection of $F$. hepatica in infected snails. After the isolation of genomic DNA with a new DNA extraction protocol using a cationic quaternary ammonium compound (CTAB), they constructed a $F$. hepatica genomic DNA library with the help of Sau 3A and plasmid transformations. Then, a selection of clones containing repetitive sequences was done using a radiolabelled probe. The sensitivity and specificity of the selected probe (GenBank Accession numbers, FHU 11818, FHU 11819) were determined through experimental infections. Quantitative blotting analysis revealed that this 124-bp repeat constitutes about $15 \%$ of the whole F. hepatica genome (Kaplan et al. 1995). In 1997, Kaplan and colleagues modified their previous protocol and used chemiluminescent detection which improved the assay efficiency. They collected from the field and analyzed more than 5,000 snails in Florida. The pFh5 probe was ${ }^{32} \mathrm{P}$-labelled or digoxigenin-labelled (Kaplan et al. 1997). One nanogram of genomic DNA of the liver fluke was detected and this level of sensitivity was not reduced by the presence of $10 \mu \mathrm{g}$ of snail DNA ( $P$. columella, or Fossaria cubensis) (Kaplan et al. 1995). Infection was detected immediately following miracidial penetration; thus a sensitivity equivalent to the minimal biologic unit of the parasite (one miracidium) was achieved. Additionally, the signal increased in a logarithmic fashion over time so that it can be used to estimate the age of infection (Kaplan et al. 1995). Using the chemiluminescent detection in a blinded study (288 snails, 32 infected) both the sensitivity and the specificity reached $100 \%$ when $200 \mathrm{ng}$ (an amount of DNA approximately equal to a 14-21-day-old infection) or less $F$. hepatica DNA was randomly added to snail DNA (Kaplan et al. 1997). However, the efficiency of the DNAextraction protocol and the sensitivity of the probe were not confirmed in a later study (Krämer 1999). The pFh5 probe did not cross hybridize with $1 \mu \mathrm{g}$ of genomic DNA of F. magna, of Paramphistomum liorchis or of Heterobilharzia americana, species which share the same enzootic range and the same intermediate hosts than those of $F$. hepatica in Florida, USA (Kaplan et al. 1995). The high degree of sequence identity explains the cross reactivity between the Fasciola-probe and DNA from $F$. hepatica and $F$. gigantica. This is a drawback in areas were both species are potentially present (Krämer and Schnieder 1998; Krämer 1999). The PCR performed on DNA from $G$. truncatula and Lymnaea pervia did not reveal any PCR products. In Fasciola sp. infected snails, PCR products with the characteristic ladder of multiple 120-bp repeats were visualized. Negative results were obtained with Paramphistomum sp. and D. dendriticum (Krämer and Schnieder 1998).

\section{Classical PCR}

PCR allows very small quantities of DNA or RNA to be selectively amplified. Several research teams used Kaplan's experiments to design PCR protocol and confirm the usefulness of this tool under field or experimental conditions (Krämer and Schnieder 1998, 1999; Krämer 1999; Mostafa et al. 2003; Velusamy et al. 2004; Caron et al. 2007). Additionally, an original PCR protocol using a fragment of the cytochrome $C$ oxidase subunit 1 gene of $F$. hepatica was compared to microscopic observation in naturally infected snails (Cucher et al. 2006).

The sequence heterogeneity of pFh5 was studied in $F$. hepatica and $F$. gigantica (36 specimens originating from five continents), by PCR, cloning and alignment (Krämer and Schnieder 1998). It was also used in a field study (Krämer 1999; Krämer and Schnieder 1999). The size of PCR-amplified sequences (usually about 120 bp) depends on the size and origin of the designed primers.

A PCR assay was used in Egypt to detect $F$. gigantica infection in Lymnaea natalensis. The amplified sequences gave the expected ladder pattern and the sensitivity and specificity were assessed during this study (Mostafa et al. 2003). The amplified products were detected as early as $1 \mathrm{~h}$ post-infection: $1 \mu \mathrm{l}$ of DNA (unknown concentration) from $L$. natalensis infected by a single miracidium of $F$. gigantica for $24 \mathrm{~h}$ and diluted 20 times showed the expected 120-bp specific band. There was no cross reactivity with other three parasites: Schistosoma mansoni, S. haematobium and Echinostoma liei, and with five snails: L. natalensis, Physa acuta, Biomphalaria alexandrina, B. truncatus and Radix auricularia (Mostafa et al. 2003). In the same way a PCR-assay was performed in India to detect $F$. gigantica in $R$. auricularia; the typical ladder pattern of the 120-bp sequence was also observed (Velusamy et al. 2004). In these two studies as well as in the work by Krämer and Schneider, the primers previously developed by Kaplan (Forward 5'-ATT CACCCATTTCTGTTAGTCC-3'; reverse 5'-ACTAGGCT TAAAGGCGTCC-3') were used.

In Belgium, a PCR based on the $\mathrm{pFh} 5$ probe was performed on G. truncatula, Radix labiata and Radix balthica experimentally infected with $F$. hepatica. This study demonstrated that this PCR is a useful tool to study the epidemiology of fasciolosis since it revealed that $R$. labiata can act as an incidental intermediate host for $F$. hepatica. No cross reaction with $R$. labiata and $R$. balthica DNA were reported (Caron et al. 2007).

The complete mitochondrial DNA sequence of $F$. hepatica (GenBank accession number, X15613.1), was used to design the pair of primer used in the next study (Forward 5'-TATGT TTTGATTTTACCCGGG-3', reverse 5'-ATGAGCAACCA CAAACCATGT-3') (Cucher et al. 2006). The positions of the primers were selected to amplify a 405 bp region of the cytochrome c oxidase subunit 1 gene. The assay detects $10 \mathrm{pg}$ of purified genomic F. hepatica DNA. This detection level was not modified by the presence of $10 \%$ of the total DNA extracted from an infection-free Lymnaea sp., but it 
increased to $100 \mathrm{pg}$ when $20 \%$ of snail DNA was added. Nevertheless, the presence of PCR inhibitors in samples was demonstrated as F. hepatica infected snails (as demonstrated microscopically) gave a negative PCR result. To overcome this problem, the PCR mix was modified by the addition of bovine serum albumine (BSA). No amplification was detected with DNA from uninfected, laboratory-reared $P$. columella and Lymnaea viatrix (Cucher et al. 2006).

\section{Multiplex PCR}

The multiplex PCR aims to amplify several sequences in the same tube and in the same time. This technique needs as much pairs of primers as sequences to be amplified. Mitochondrial DNA (mDNA) was used in a multiplex PCR technique to identify larval stages of $F$. hepatica in experimentally infected snails in Brazil (Magalhaes et al. 2004). From another complete mitochondrial DNA sequence of $F$. hepatica (Genbank accession number, AF216697), specific primers were designed for a conserved and repetitive region of this trematode. A pair of primers was used in $F$. hepatica experimentally infected $P$. columella during the prepatent period simultaneously with another pair of primers which amplified, under high stringency conditions, the internal transcribed spacer (ITS) region of the trematode and the mollusc rDNA, thus acting as an internal control (Magalhaes et al. 2004). PCR products were visualized on $6 \%$ silver-stained polyacrylamide gels. Amplification of $F$. hepatica specific mDNA was achieved and a ladder pattern with intervals of 85 nucleotides was visible. Such pattern mirrored the amplification of a tandem repeat DNA region (Magalhaes et al. 2004). The reaction was sensitive, as it detected a single miracidium $(0.8 \mathrm{ng} / \mu \mathrm{l})$ of $F$. hepatica in the presence of snail DNA $(7 \mathrm{ng} / \mu \mathrm{l})$. Specific amplification was obtained in infected snails as soon as 1 day post-exposure. The designed primers were specific for $F$. hepatica detection, as demonstrated by the band profiles obtained from snails infected with this trematode and other species commonly found in P. columella (Magalhaes et al. 2004).

\section{Real time PCR}

This technique is based on the $5^{\prime}-3^{\prime}$ exonuclease activity of the Taq DNA polymerase, which results in the cleavage of fluorescent dye-labelled TaqMan probe during PCR; the intensity of fluorescence is then measured by a sequence detection system which is proportional to the amount of PCR product formed. Recently, a quantitative real time PCR assay was designed and evaluated in naturally infected $G$. truncatula (Schweizer et al. 2007). Primers and probe were designed to amplify an 86-pb-long target of a repetitive 449-bp-long genomic DNA fragment cloned during a previous study (clone Fhr-II, Genbank accession number, S67037) (Heussler et al. 1993). The sensitivity of the de- tection of $F$. hepatica with this technique was not evaluated (Schweizer et al. 2007).

\section{Advantages and disadvantages of screening methods}

Tables 2 and 3 list the advantages and drawbacks of the different methods used to study digenean infections in snails. If snail squashing is particularly well-adapted for detecting natural infections in snails collected from the field, its use is limited to the evaluation of the prevalence of infection. Snail dissection is the best method in the case of experimentally infected snails, as the infection rate and, in a lesser extent, the intensity of infection and metacercarial production can be assessed. Histological examination is time-consuming and fairly expensive but it allows an accurate evaluation of larval forms in the snail. Cercarial shedding has a limited value, as it gives only information on the dynamics of shedding in naturally or experimentally infected snails.

The enzyme electrophoresis in starch gel is a very cheap and simple biochemical method that could be used in a very

Table 2 Advantages and drawbacks of different techniques used to study the presence of Fasciola sp. in its intermediate host

\begin{tabular}{|c|c|c|c|}
\hline \multirow[t]{2}{*}{ Technique } & \multicolumn{3}{|c|}{$\begin{array}{l}\text { Value of each technique (from } 0 \text { to }+++ \text { ) } \\
\text { for determining }\end{array}$} \\
\hline & $\begin{array}{l}\text { Prevalence of } \\
\text { infection }\end{array}$ & $\begin{array}{l}\text { Intensity of } \\
\text { infection }\end{array}$ & $\begin{array}{l}\text { Metacercarial } \\
\text { production }\end{array}$ \\
\hline Snail squashing ${ }^{\mathrm{a}}$ & +++ & + & $0 /+$ \\
\hline Snail dissection $^{\mathrm{b}}$ & +++ & ++ & ++ \\
\hline $\begin{array}{l}\text { Cercarial } \\
\text { shedding }^{\mathrm{c}}\end{array}$ & + & + & +++ \\
\hline $\begin{array}{l}\text { Histological } \\
\text { methods }^{\mathrm{d}}\end{array}$ & ++ & +++ & 0 \\
\hline $\begin{array}{l}\text { Enzyme } \\
\text { electrophoresis }\end{array}$ & +++ & 0 & 0 \\
\hline $\begin{array}{l}\text { RNA-based } \\
\text { blotting }^{\text {f }}\end{array}$ & +++ & + & 0 \\
\hline $\begin{array}{l}\text { DNA-based } \\
\text { blotting }\end{array}$ & +++ & ++ & 0 \\
\hline PCR basic ${ }^{\mathrm{h}}$ & +++ & 0 & 0 \\
\hline PCR multiplex ${ }^{\mathrm{i}}$ & +++ & 0 & 0 \\
\hline Real time $\mathrm{PCR}^{\mathrm{j}}$ & +++ & No data & 0 \\
\hline
\end{tabular}

${ }^{\text {a }}$ Dreyfuss et al. (2005)

${ }^{\mathrm{b}}$ Abrous et al. (1999, 2000), Mage et al. (2002)

${ }^{\mathrm{c}}$ Vignoles et al. (2002)

${ }^{\mathrm{d}}$ Rondelaud and Barthe (1982, 1987)

${ }^{\mathrm{e}}$ Van Aken (1982), Van Aken and Brandt (1987)

${ }^{\mathrm{f}}$ Shubkin et al. (1992), Rognlie et al. (1994, 1996)

${ }^{\mathrm{g}}$ Heussler et al. (1993), Kaplan et al. (1995, 1997)

${ }^{\mathrm{h}}$ Krämer and Schnieder (1998), Mostafa et al. (2003), Velusamy et al. (2004), Cucher et al. (2006), Caron et al. (2007)

${ }^{i}$ Magalhaes et al. (2004)

${ }^{\mathrm{j}}$ Heussler et al. (1993), Schweizer et al. (2007) 
Table 3 Sensitivity, specificity, easiness, and cost of the techniques used for the detection of Fasciola sp. in their intermediate host

\begin{tabular}{|c|c|c|c|c|}
\hline \multirow[t]{2}{*}{ Technique } & \multicolumn{4}{|c|}{$\begin{array}{l}\text { Interest of each technique (from } 0 \text { to }+++ \text { ) } \\
\text { for determining }\end{array}$} \\
\hline & Sensitivity & Specificity & Easiness & Cost \\
\hline Snail squashing ${ }^{a}$ & + & + & +++ & + \\
\hline Snail dissection ${ }^{\mathrm{b}}$ & + & ++ & ++ & + \\
\hline Cercarial shedding $^{\mathrm{c}}$ & ++ & + & + & + \\
\hline $\begin{array}{l}\text { Histological } \\
\text { methods }^{\mathrm{d}}\end{array}$ & ++ & ++ & + & + \\
\hline $\begin{array}{l}\text { Enzyme } \\
\text { electrophoresis }^{\mathrm{e}}\end{array}$ & + & No data & +++ & + \\
\hline RNA-based blotting $^{\mathrm{f}}$ & +++ & ++ & + & +++ \\
\hline DNA-based blotting ${ }^{\mathrm{g}}$ & +++ & ++ & ++ & +++ \\
\hline PCR basic ${ }^{\mathrm{h}}$ & $+++/++$ & +++ & +++ & ++ \\
\hline PCR multiplex ${ }^{\mathrm{i}}$ & +++ & ++ & ++ & ++ \\
\hline Real time $\mathrm{PCR}^{\mathrm{j}}$ & +++ & ++ & + & +++ \\
\hline
\end{tabular}

${ }^{\mathrm{a}}$ Dreyfuss et al. (2005)

${ }^{b}$ Abrous et al. (1999, 2000), Mage et al. (2002)

${ }^{\mathrm{c}}$ Vignoles et al. (2002)

${ }^{\mathrm{d}}$ Rondelaud and Barthe (1982, 1987)

${ }^{\mathrm{e}}$ Van Aken (1982), Van Aken and Brandt (1987)

${ }^{\mathrm{f}}$ Shubkin et al. (1992), Rognlie et al. (1994, 1996)

${ }^{g}$ Heussler et al. (1993), Kaplan et al. (1995, 1997)

${ }^{\mathrm{h}}$ Krämer and Schnieder (1998), Mostafa et al. (2003), Velusamy et al. (2004), Cucher et al. (2006), Caron et al. (2007)

${ }^{i}$ Magalhaes et al. (2004)

${ }^{\mathrm{j}}$ Heussler et al. (1993), Schweizer et al. (2007)

modest laboratory for a preliminary selection of possible intermediate hosts in a particular epidemiological context but the check out can be difficult (enzyme choice, temperature, chemical revelation). The specificity and sensitivity of the technique is poor when compared with DNA/RNA-based techniques and consequently it is not used anymore.

Blotting is not very easy and needs a fairly expensive equipment as it imposes the use of radiolabelled $\left.{ }^{32} \mathrm{P}\right)$ or chemicoluminescent-labelled (digoxigenin) probes. Several steps (which increase the contamination risk) are necessary: RNA or DNA extractions, reverse transcription if necessary, PCR, blotting, and hybridization: making this technique very time-consuming (at least 1 day). Contamination with RNAase is a real problem. However, the chemiluminescence detection is faster, safer, more sensitive, and less expensive than radioisotopic detection (Kaplan et al. 1997); with both revelation methods quantification is possible. For the entire assay including solutions, reagents, enzymes, and disposables, the cost is 0.22 to 0.24 Euro per sample (Kaplan et al. 1995). However, the laboratory must be equipped with heavy material such as thermal cycler, incubator, and radiological or chemicoluminescent revelation system.

The molecular biology techniques are based on blotting or on PCR, and on various kinds of nucleic acids. The extraction of DNA or RNA is always the first step. It has to be quick, cheap, safe, and easy to perform during large epidemiological surveys. This is not the case for the proteinase $\mathrm{K} / \mathrm{phenol} /$ chloroform extraction protocol which necessitates many steps and is time consuming (overnight incubation). The use of CTAB (Kaplan et al. 1995) or even better, that of Chelex ${ }^{\circledR}$ (Walsh et al. 1991) eliminates the overnight incubation and allows the DNA extraction from 100 samples in less than $4 \mathrm{~h}$ at a very low cost (0.004 Euro per snail).

The principal advantage of the PCR is its high sensitivity and specificity contrary to DNA probes because the sequence amplified is always accurately targeted with primers. However, the hybridation process depends on the stringency of the reaction conditions. A thermal cycler (PCR), or a radiologic or luminescent detection system (DNA probe) is necessary. A disadvantage of the PCR is the possibility of false-negative (from PCR inhibitors) or false-positive (from carryover contamination) but the use of BSA or internal control can resolve this point (Magalhaes et al. 2004; Cucher et al. 2006). The PCR reaction takes only three to $4 \mathrm{~h}$ and many commercially available kits can facilitate the whole process. The amplification products are electrophoretically resolved in agarose gels and stained with ethidium bromide. This last step takes $2 \mathrm{~h}$ only. An optimized PCR protocol allows the analysis of up to 200 samples in less than $10 \mathrm{~h}$. The cost is about 0.3 Euro per snail.

Magalhaes et al. (2004) recommended the use of an internal control in their multiplex PCR protocol. This is questionable because it complicates the process and cross hybridization between the four primers might occur.

In the case of $F$. hepatica infected snails, different types of nucleic acids can be amplified by PCR for $F$. hepatica diagnosis. First, in growing cells, rRNA is the most abundant nucleic acid present. An additional amplification system like PCR may not be even needed (Shubkin et al. 1992). Ribosomal DNA or RNA contain highly repeated sequences; sensitivity is high but specificity may be reduced because repeat sequences tend to be conserved between closely related species (Waters and McCuthan 1990). Secondly, repetitive DNA sequences (interspersed repetitive sequences) are interesting because they are often present in high levels. Additionally, these sequences evolve more rapidly than gene coding sequences making them excellent candidates for speciesspecific probes for eukaryotic organisms (McLaughlin et al. 1987). Thirdly, specific sequences of genomic DNA are highly specific for a given species (cytochrome C oxidase subunit 1 gene, or ITS for instance). While specificity is high, sensitivity may be lower when compared to highly repeated sequences. However, PCR can overcome a lack of sensitivity by greatly amplifying the sequence of interest (Prichard 1997).

Real time PCR is difficult to perform particularly with regard to the determination of the experimental conditions of the 
reaction (design of the TaqMan probe, optimization of $\mathrm{E}_{\mathrm{PCR}}$ ) and result interpretation. It is an expensive technique because of the TaqMan probe (about 150 Euros), and the price of the fluorescence detection system (about 20,000 Euros). Real-time PCR has a major advantage: it allows the quantification of nucleic acid sequences in a sample. The signal intensity of a basic PCR is very difficult to interpret in a quantitative way because we cannot know if the signal reflects the exponential step or not, contrary to real time PCR where the cycle threshold $\left(C_{\mathrm{t}}\right)$ value is calculated in the exponential measurable step. Sensitivity and specificity are comparable in both techniques as well as reproductibility at a lower extent; However, real-time PCR is faster and does not need a detection step post-PCR (agarose or polyacrylamide gels) since amplification and detection are done simultaneously.

\section{Conclusions}

According to Barker (1994), "PCR is likely to have a profound effect upon parasitological studies precisely because it provides the means to answer questions which have otherwise been difficult to address". We can add that in the case of $F$. hepatica and its snail hosts, the ideal screening technique does not exist simply because each available technique addresses different questions (Tables 2 and 3).

Snail crushing and dissection are simple and allow the direct detection of naturally and experimentally infected snails. Furthermore, distinct larval stages can be identified. However, the calculation of the prevalence and intensity of infection is slow, labor-consuming, tedious, and is only feasible in fairly heavily infected snails. Finally, it requires an experienced microscopist. Detection is usually feasible on day 8 onwards after exposure to miracidia and maintenance at $20^{\circ} \mathrm{C}$. The monitoring of cercarial shedding is a very useful criterion which gives information on intermediate host capacity and pasture contamination. Histological methods allow the detection of the larval stages in the snail in a quantitative and qualitative way. The biochemical technique is not used anymore and will not be discussed further.

The different techniques based on the use of molecular biology were used mainly under experimental conditions. Indeed, very few studies assessed the level of infection under field conditions (Rognlie et al. 1996; Kaplan et al. 1997; Cucher et al. 2006; Schweizer et al. 2007) and in only two, a comparison was made with microscopic techniques (Kaplan et al. 1997; Cucher et al. 2006). Cucher and colleagues (2006) analyzed 240 snails naturally exposed to $F$. hepatica and found $17.5 \%$ and $51.3 \%$ of positive snails, respectively, by microscopy and PCR (this difference was statistically significant). Kaplan and colleagues (1997) compared the same techniques during the course of an experimental infection (take $=90 \%$ ): snails were examined on days $7,14,21,28$, and
42 post-infection. The DNA-based technique was more sensitive, especially at the beginning of the larval development.

Blotting is not acceptable for field use because it is a fairly complicated technique which implies the use of radiolabelled reporter molecules (Weiss 1995) or chemiluminescence. However, it allows the assessment of new sequences that can served to set up a PCR. Very often, PCR tends to be considered as the golden standard because of its high sensitivity and specificity (Barker 1994; Kaplan et al. 1997). However, a traditional PCR brings no information concerning the parasitic load in the snail and metacercarial production. Additionally, PCR does not give any information about the viability of the parasite. Consequently, a positive PCR signal in a given snail species does not mean necessarily that this species is able to sustain the whole parasite cycle leading to cercarial shedding. Real time PCR can give very accurate data concerning the intensity of infection. However, this is an expensive technique so that snail dissection or histological examination can accurately address this point. The choice of a technique must also take into consideration its cost and easiness and large differences can be noticed (Cancrini and Iori 2004).

It is important to point out that, at the time being, there is not a single technique which is simple, robust, reproducible and cheap enough for a field use. As PCR detects accurately parasite invasion and microscopic examination reveals successful infections in the snail host, both techniques could be used together to achieve a more comprehensive understanding of the epidemiological situation in a given area and to assess the capacity of different intermediate host to sustain larval development (Hamburger et al. 2004; Cucher et al. 2006).

\section{References}

Abrous M, Rondelaud D, Dreyfuss G, Cabaret J (1999) Infection of Lymnaea truncatula and Lymnaea glabra by Fasciola hepatica and Paramphistomum daubneyi in farms of central France. Vet Res 30:113-118

Abrous M, Rondelaud D, Dreyfuss G (2000) A field study of natural infections in three freshwater snails with Fasciola hepatica and/ or Paramphistomum daubneyi in central France. J Helminthol 74:189-194

Audousset JC, Rondelaud D, Dreyfuss G, Vareille-Morel C (1989) Les émissions cercariennes de Fasciola hepatica L. chez le mollusque Lymnaea truncatula Müller. A propos de quelques observations chronobiologiques. Bull Soc Fr Parasitol 7:217-224

Barber IW (1962) The pathology produced in the snail Lymnaea columella Say, 1817, by the larval stages of Fasciola hepatica L., 1758. University of California, Berkeley

Barker RH Jr. (1994) Use of PCR in the field. Parasitol Today 10:117119

Barry T, Rowel R, Gannon F (1990) A general method to generate DNA probes for microorganisms. Biotechnology 8:233-236

Belfaiza M, Rondelaud D, Moncef M, Dreyfuss G (2004a) Fasciola hepatica: cercarial productivity of redial generations in longsurviving Galba truncatula. J Helminthol 78:115-120 
Belfaiza M, Rondelaud D, Moncef M, Dreyfuss G (2004b) Fasciola hepatica: the effect of food quality on the development of redial generations in Galba truncatula infected with allopatric miracidia. Parasitol Res 92:12-17

Belfaiza M, Moncef M, Rondelaud D (2005) Fasciola hepatica: an unusual case of adaptation to a Moroccan population of Galba truncatula. Parasitol Res 95:374-378

Boray JC (1978) The potential impact of exotic Lymnaea spp. on fascioliasis in Australasia. Vet Parasitol 4:127-141

Calvopina M, Armijos RX, Marco JD, Uezato H, Kato H, Gomez EA, Korenaga M, Barroso PA, Mimori T, Cooper PJ, Nonaka S, Hashiguchi Y (2006) Leishmania isoenzyme polymorphisms in Ecuador: relationships with geographic distribution and clinical presentation. BMC Infect Dis 6:139

Cancrini G, Iori A (2004) Traditional and innovative diagnostic tools: when and why they should be applied. Parassitologia 46:173-176

Caron Y, Lasri S, Losson B (2007) Fasciola hepatica: an assessment on the vectorial capacity of Radix labiata and $R$. balthica commonly found in Belgium. Vet Parasitol 149:95-103

Cucher MA, Carnevale S, Prepelitchi L, Labbe JH, Wisnivesky-Colli C (2006) PCR diagnosis of Fasciola hepatica in field-collected Lymnaea columella and Lymnaea viatrix snails. Vet Parasitol 137:74-82

Dassler HG, Schmiedel T (1989) Ultrathin-layer starch gel electrophoresis: a method qualified to solve specific problems in enzyme analysis. Pharmazie 44:34-36

Delves CJ, Goman M, Ridley RG, Matile H, Lensen TH, Ponnudurai T, Scaife JG (1989) Identification of Plasmodium falciparuminfected mosquitoes using a probe containing repetitive DNA. Mol Biochem Parasitol 32:105-112

Dreyfuss G, Rondelaud D (1995) Comparative studies on the productivity of Fasciola gigantica and F. hepatica sporocysts in Lymnaea tomentosa that died after a cercarial shedding or without emission. Parasitol Res 81:531-536

Dreyfuss G, Vignoles P, Rondelaud D (2005) Fasciola hepatica: epidemiological surveillance of natural watercress beds in central France. Parasitol Res 95:278-282

Erhardová-Kotrlá B (1971) The occurrence of Fascioloides magna (Bassi, 1875) in Czechoslovakia. Academia, Prague

Gasser RB (1999) PCR-based technology in veterinary parasitology. Vet Parasitol 84:229-258

Graczyk TK, Fried B (1999) Development of Fasciola hepatica in the intermediate host. In: Dalton JP (ed) Fasciolosis. CABI, Wallingford, Oxon, pp 31-46

Hamburger J, Hoffman O, Kariuki HC, Muchiri EM, Ouma JH, Koech DK, Sturrock RF, King CH (2004) Large-scale, polymerase chain reactionbased surveillance of Schistosoma haematobium DNA in snails from transmission sites in coastal Kenya: a new tool for studying the dynamics of snail infection. Am J Trop Med Hyg 71:765-773

Heussler V, Kaufmann H, Strahm D, Liz J, Dobbelaere D (1993) DNA probes for the detection of Fasciola hepatica in snails. Mol Cell Probes 7:261-267

Hodasi JK (1972) The output of cercariae of Fasciola hepatica by Lymnaea truncatula and the distribution of metacercariae on grass. Parasitology 64:53-60

Hubscher U (1991) DNA diagnosis in veterinary medicine: II. Polymerase chain reaction (PCR). Schweiz Arch Tierh.kd 133:27-31

Kaplan RM, Dame JB, Reddy GR, Courtney CH (1995) A repetitive DNA probe for the sensitive detection of Fasciola hepatica infected snails. Int J Parasitol 25:601-610

Kaplan RM, Dame JB, Reddy GR, Courtney CH (1997) The prevalence of Fasciola hepatica in its snail intermediate host determined by DNA probe assay. Int J Parasitol 27:1585-1593

Kendall SB, McCullough FS (1951) The emergence of cercariae of Fasciola hepatica from the snail Limnaea truncatula. J Helminthol 25:77-92
Krämer F (1999) Eignung einer Gensonde zum nachweis Derentwicklungsstadien von Fasciola hepatics Linne 1758 im Zwischenwirt. Tierärztliche Hoschschule, Hannover

Krämer F, Schnieder T (1998) Sequence heterogeneity in a repetitive DNA element of Fasciola. Int J Parasitol 28:1923-1929

Krämer F, Schnieder T (1999) Untersuchungen über den Zwischenwirt von Fasciola hepatica mittels einer DNA-Sonde zur Etablierung eines epidemiologischen Diagnostikverfahrens. PrakTierarzt $80: 520-529$

Kukla BA, Majiwa PA, Young JR, Moloo SK, ole-MoiYoi OK (1987) Use of species-specific DNA probes for detection and identification of trypanosome infection in tsetse flies. Parasitology 95:1-16

Le Riche PD, Sewell MM (1977) Differentiation of Taenia saginata and Taenia solium by enzyme electrophoresis. Trans R Soc Trop Med Hyg 71:327-328

Le Riche PD, Sewell MM (1978a) Identification of Echinococcus granulosus strains by enzyme electrophoresis. Res Vet Sci 25:247-248

Le Riche PD, Sewell MM (1978b) Differentiation of taeniid cestodes by enzyme electrophoresis. Int J Parasitol 8:479-483

Magalhaes KG, Passos LK, Carvalho Odos S (2004) Detection of Lymnaea columella infection by Fasciola hepatica through Multiplex-PCR. Mem Inst Oswaldo Cruz 99:421-424

Mage C, Bourgne H, Toullieu JM, Rondelaud D, Dreyfuss G (2002) Fasciola hepatica and Paramphistomum daubneyi: changes in prevalences of natural infections in cattle and in Lymnaea truncatula from central France over the past 12 years. Vet Res 33:439-447

McLaughlin GL, Collins WE, Campbell GH (1987) Comparison of genomic, plasmid, synthetic, and combined DNA probes for detecting Plasmodium falciparum DNA. J Clin Microbiol 25:791-795

Mostafa OM, Taha HA, Ramadan G (2003) Diagnosis of Fasciola gigantica in snail using the polymerase chain reaction (PCR) assay. J Egypt Soc Parasitol 33:733-742

Moukrim A, Zekhnini A, Rondelaud D (1995) A comparative study of the shedding of cercariae of Schistosoma haematobium in newborn Bulinus truncatus. Parasitol Res 81:537-539

Pointier JP, Coustau C, Rondelaud D, Theron A (2007) Pseudosuccinea columella (Say 1817) (Gastropoda, Lymnaeidae), snail host of Fasciola hepatica: first record for France in the wild. Parasitol Res 101:1389-1392

Prichard R (1997) Application of molecular biology in veterinary parasitology. Vet Parasitol 71:155-175

Rognlie MC, Dimke KL, Knapp SE (1994) Detection of Fasciola hepatica in infected intermediate hosts using RT-PCR. J Parasitol 80:748-755

Rognlie MC, Dimke KL, Potts RS, Knapp SE (1996) Seasonal transmission of Fasciola hepatica in Montana, USA, with detection of infected intermediate hosts using a DNA-based assay. Vet Parasitol 65:297-305

Rondelaud D, Barthe D (1980a) Données histopathologiques sur l'épithélium génital de Lymnaea truncatula Müller infestée par Fasciola hepatica L. Bull Soc Zool Fr 105:481-490

Rondelaud D, Barthe D (1980b) Fasciola hepatica L.: les formes larvaires non évolutives ou en dégénérescence chez Lymnaea truncatula Müller. Z Parasitenkd 62:95-104

Rondelaud D, Barthe D (1982) Les générations rédiennes de Fasciola hepatica L. chez Lymnaea truncatula Müller. A Propos des effets de plusieurs facteurs. Ann Parasitol Hum Comp 57:245-261

Rondelaud D, Barthe D (1983) Les modifications stucturales du rein chez Lymnaea truncatula Müller infestée par Fasciola hepatica L. Ann Parasitol Hum Comp 58:109-116

Rondelaud D, Barthe D (1987) Fasciola hepatica L.: the productivity of a sporocyst as a function of the size of Lymnaea truncatula Muller. Parasitol Res 74:155-160 
Saiki RK, Scharf S, Faloona F, Mullis KB, Horn GT, Erlich HA, Arnheim N (1985) Enzymatic amplification of $\beta$-globin genomic sequences and restriction site analysis for the diagnosis of sicklecell anemia. Science 230:1350-1354

Schweizer G, Meli ML, Torgerson PR, Lutz H, Deplazes P, Braun U (2007) Prevalence of Fasciola hepatica in the intermediate host Lymnaea truncatula detected by real time TaqMan PCR in populations from 70 Swiss farms with cattle husbandry. Vet Parasitol 150:164-169

Severson WE (1991) The development of a diagnostic assay for Tritrichomonas foetus. Montana State University, Bozeman

Shubkin CD, White MW, Abrahamsen MS, Rognlie MC, Knapp SE (1992) A nucleic acid-based test for detection of Fasciola hepatica. J Parasitol 78:817-821

Taylor EL (1965) Fascioliasis and the liver fluke. FAO agricultural studies edition.vol 64. FAO Agricultural Studies, Rome

Torgerson P, Claxton J (1999) Epidemiology and control. In: Dalton JP (ed) Fasciolosis. CABI, Wallingford, Oxon, pp 113-149

Van Aken D (1982) Detection of the larval stages of Fasciola hepatica in Lymnaea truncatula by enzyme electrophoresis, Diergeneeskunde IvTGA, ed. Instituut voor Tropische Geneeskunde Afdeling Diergeneeskunde, Antwerpen

Van Aken D, Brandt J (1987) Preliminary observations on the detection of the larval stages of Fasciola hepatica in Lymnaea truncatula by enzyme-electrophoresis. Ann Soc Belge Med Trop 67:295-298
Velusamy R, Singh BP, Raina OK (2004) Detection of Fasciola gigantica infection in snails by polymerase chain reaction. Vet Parasitol 120:85-90

Vignoles P, Dreyfuss G, Rondelaud D (2002) Larval development of Fasciola hepatica in experimental infections: variations with populations of Lymnaea truncatula. J Helminthol 76:179-183

Vignoles P, Rondelaud D, Dreyfuss G (2008) Paramphistomum daubneyi: production dynamics and infectivity of metacercariae originating from snails dissected at regular intervals. J Helminthol $82: 175-180$

Walsh PS, Metzger DA, Higuchi R (1991) ChelexÒ100 as a medium for simple extraction of DNA for PCR-based typing from forensic material. Biotechnology 10:506-513

Waters AP, McCuthan TF (1990) Ribosomal RNA: nature's own polymerase-amplified target for diagnosis. Parasitol Today 6:56-59

Webster P, Mansour TE, Bieber D (1989) Isolation of a female-specific, highly repeated Schistosoma mansoni DNA probe and its use in an assay of cercarial sex. Mol Biochem Parasitol 36:217-222

Weiss JB (1995) DNA probes and PCR for diagnosis of parasitic infections. Clin Microbiol Rev 8:113-130

Yeo M, Lewis MD, Carrasco HJ, Acosta N, Llewellyn M, da Silva Valente SA, de Costa Valente V, de Arias AR, Miles MA (2007) Resolution of multiclonal infections of Trypanosoma cruzi from naturally infected triatomine bugs and from experimentally infected mice by direct plating on a sensitive solid medium. Int J Parasitol 37:111-120 